International Journal of Engineering, Science and Technology

Vol. 1, No. 1, 2009, pp. 245-253
INTERNATIONAL

JOURNAL OF

ENGINEERING,

SCIENCE AND

TECHNOLOGY

www.ijest-ng.com

(C) 2009 MultiCraft Limited. All rights reserved

\title{
Effects of superficial gas velocity and fluid property on the hydrodynamic performance of an airlift column with alcohol solution
}

\author{
V. Sivasubramanian ${ }^{\mathrm{a}}$ and B.S. Naveen Prasad ${ }^{\mathrm{b}}$ \\ ${ }^{a}$ Department of Chemical Engineering, National Institute of Technology Calicut, Kerala-673601, India \\ ${ }^{b}$ Department of Chemical Engineering, Sathyabama University, Chennai, India \\ E-mail: (siva@nitc.ac.in (V. Sivasubramanian), "Corresponding author),Tel: 0495-2286525, 2286544
}

\begin{abstract}
In the present study, the influence of superficial gas velocity and fluid properties on gas holdup and liquid circulation velocity in a three-phase external loop airlift column using polystyrene $\left(0.0036 \mathrm{~m}\right.$ diameter and $1025.55 \mathrm{~kg} / \mathrm{m}^{3}$ density $)$ and nylon-6 $\left(0.0035 \mathrm{~m}\right.$ diameter and $1084.24 \mathrm{~kg} / \mathrm{m}^{3}$ density) particles with aqueous solutions of alcohols (isoamyl alcohol and propanol) as liquids were investigated. The column was constructed using acrylic tube of inner diameter $0.084 \mathrm{~m}$ and $2.6 \mathrm{~m}$ in height. The gas holdup in the riser increased with increase in superficial gas velocity for air-alcohol-solid system. The presence of alcohol surfactants increased the gas holdup in the riser. It was also found that an increase in the superficial gas velocity increased the liquid circulation velocity for air-alcohol-solid system. Correlations were proposed for the prediction of gas holdup and liquid circulation velocity.
\end{abstract}

Keywords: External loop airlift bioreactor, three-phase, effect of additives, hydrodynamics

\section{Introduction}

Airlift reactors have several advantages: simple design concept, high mixing performance, high mass transfer ability, good heat transfer and low energy consumption. Airlift loop reactors find extensive applications in many areas of chemical engineering, especially for homogeneous as well as heterogeneous single and multiphase systems due to their simple construction and operation, directed circulation flow, good mixing and favorable ratio of interfacial area to energy dissipation rate per unit volume, low investment, operational costs and relatively lower power requirements (Merchuk and Siegel, 1988). Based on their configurations, airlift reactors can be classified into two groups: internal-loop and external-loop airlift reactors. An internal-loop airlift reactor contains a vertical baffle or a draft tube by which a loop channel for fluid circulation is formed in the reactor. An external-loop airlift reactor consists of two vertical tubes (a riser and a downcomer) which are connected by horizontal connections at the top and bottom. A distractive difference between the two groups is the presence of the horizontal connections (Choi, 2001).

Herskowitz and Merchuk (1986) reported the influence of solid particles on the gas hold and liquid superficial velocity in a novel three phase fluidized bed reactor. Posarac and Petrovic (1988) found that the minimum fluidization velocity of 3-6 mm glass spheres was found to increase with solids loading. Kochbeck et al. (1992) reported the hydrodynamics and local parameters in three-phase-flow in airlift-loop reactors of different scale. Douek et al. (1994) observed that gas holdup and the liquid circulation velocity in the riser increased with increase in gas superficial velocity. A new method for the measurement of solids holdup in gasliquid-solid three-phase systems was proposed by Wenge et al. (1995). Guo et al. (1997) reported the influence of hydrodynamics and mass transfer studies in a novel external-loop airlift reactor. Freitas et al. (1997) proposed a new sampling device for measuring solids holdup in a three-phase system. Freitas and Teixeira (1998) reported on solid-phase distribution in an airlift reactor with an enlarged degassing zone.

Freitas et al. (2000) reported the influence of the diameter of the distributor orifice, superficial gas velocity, solid loading and solid density on the hydrodynamics of a three-phase external-loop airlift bioreactor. The development and use of simple method for regime identification and flow characterization in bubble columns and airlift reactors was reported by Vial et al. (2001). Shimizu et al. (2001) developed the phenomenological simulation model for prediction of gas hold-up and volumetric mass 
transfer coefficients in external-loop airlift reactors. Meng et al. (2002) reported the use of a modified volume expansion (inclined tube) method for determination of overall gas holdup in an external loop airlift bubble column. Wang et al. (2003) reported the determination of gas holdup, liquid circulating velocity and mass transfer coefficient in a mini-scale external- loop airlift bubble column. Blazej et al. (2004) reported the simulation of gas-liquid flow in an airlift reactor using commercially available software Fluent.

From the literature, it is observed that most of the studies used pure water as liquid while all applications in wastewater treatment or biochemical reactors use complex aqueous solutions. Studies conducted with regular fluidized beds have shown that the presence of minor liquid impurities can greatly affect the bed hydrodynamics (Saberian-Broujenni et al., 1984; Nacef et al., 1988; Song et al., 1989; Prakash, 1991; Del Pozo et al., 1994). However, little attention has been focused on the effect of additives in the hydrodynamic performance studies in external loop airlift bioreactors. The main objective of the present study is to establish whether changes in liquid coalescing properties caused by minute concentrations of additives can greatly affect the hydrodynamic properties of a three-phase external loop airlift column and to investigate the influence of superficial gas velocity and fluid properties on gas holdup and liquid circulation velocity.

\section{Material and methods}

The schematic diagram of the external loop airlift column used in the present investigation is shown (Figure 1). The column was constructed using acrylic tube of inner diameter $0.084 \mathrm{~m}$ and $2.6 \mathrm{~m}$ in height. The column consisted of four sections namely riser, downcomer, base and gas-liquid separator. The riser and downcomer were connected with an inclined angle $45^{\circ}$ at the top and the bottom section of the column. In order to avoid solids settling, the connection pipes between the riser and downcomer were inclined. The external loop airlift column had a perforated plate gas sparger with 243 holes of $1 \mathrm{~mm}$ diameter on a triangular pitch placed at the base of the column. Air from the compressor was sparged to the column through an air filter, pressure regulator and calibrated rotameter. Provision was made to insert the dissolved oxygen meter probe above the gas sparger. All runs were made at room temperature $\left(25 \pm 2^{\circ} \mathrm{C}\right)$.

The solid particles used are polystyrene of $0.0036 \mathrm{~m}$ diameter $\left(1025.55 \mathrm{~kg} / \mathrm{m}^{3}\right.$ density) and nylon- 6 of $0.0035 \mathrm{~m}$ diameter $\left(1084.24 \mathrm{~kg} / \mathrm{m}^{3}\right.$ density). The physical properties of aqueous solutions of alcohols were given in Table 1 . The gas holdup in the riser in three-phase system was determined by manometric technique and the liquid circulation velocity in the downcomer of the column was determined by tracer technique using $10 \mathrm{~mm}$ polystyrene spherical particle of density of $1012 \mathrm{~kg} / \mathrm{m}^{3}$.

Table 1. Physical properties of aqueous solutions of isoamyl alcohol and propanol

\begin{tabular}{ccccc}
\hline Additive & Concentrations & $\begin{array}{c}\text { Density, } \\
\rho_{1}\left(\mathrm{~kg} / \mathrm{m}^{3}\right)\end{array}$ & $\begin{array}{c}\text { Viscosity, } \\
\mu_{1}(\mathrm{mPa} . \mathrm{s})\end{array}$ & $\begin{array}{c}\text { Surface tension, } \\
\sigma_{1}(\mathrm{~N} / \mathrm{m})\end{array}$ \\
\hline Isoamyl alcohol & $20 \mathrm{mg} / \mathrm{l}$ & 998 & 1.0 & 0.072 \\
Isoamyl alcohol & $40 \mathrm{mg} / \mathrm{l}$ & 998 & 1.0 & 0.071 \\
Isoamyl alcohol & $60 \mathrm{mg} / \mathrm{l}$ & 998 & 0.98 & 0.069 \\
Isoamyl alcohol & $80 \mathrm{mg} / \mathrm{l}$ & 998 & 0.97 & 0.069 \\
Isoamyl alcohol & $100 \mathrm{mg} / 1$ & 997 & 0.97 & 0.067 \\
Propanol & $0.1 \mathrm{wt} \%$ & 998 & 1.0 & 0.072 \\
Propanol & $0.2 \mathrm{wt} \%$ & 998 & 1.0 & 0.072 \\
Propanol & $0.3 \mathrm{wt} \%$ & 998 & 0.98 & 0.070 \\
Propanol & $0.4 \mathrm{wt} \%$ & 998 & 0.97 & 0.069 \\
Propanol & $0.5 \mathrm{wt} \%$ & 998 & 0.97 & 0.068 \\
\hline
\end{tabular}

\subsection{Measurement of gas holdup in three-phase system}

In the three-phase systems, two different types of solid particles Polystyrene and Nylon-6 at various solids loading were used and the solid loadings were varied from 1000-3000 $\mathrm{ml}(4.25-12.765 \%$ (Vol.)). The gas holdup in the riser in three-phase system was determined by manometric technique and are related to solid holdup, $\phi_{\mathrm{s}}$ by

$$
\epsilon_{g r}=\left(\frac{\left(\rho_{s}-\rho_{l}\right) \phi_{s}+\left(\rho_{l} \Delta h / z\right)}{\left(\rho_{s}-\rho_{l}\right) \phi_{s}+\left(\rho_{l}-\rho_{g}\right)}\right)
$$




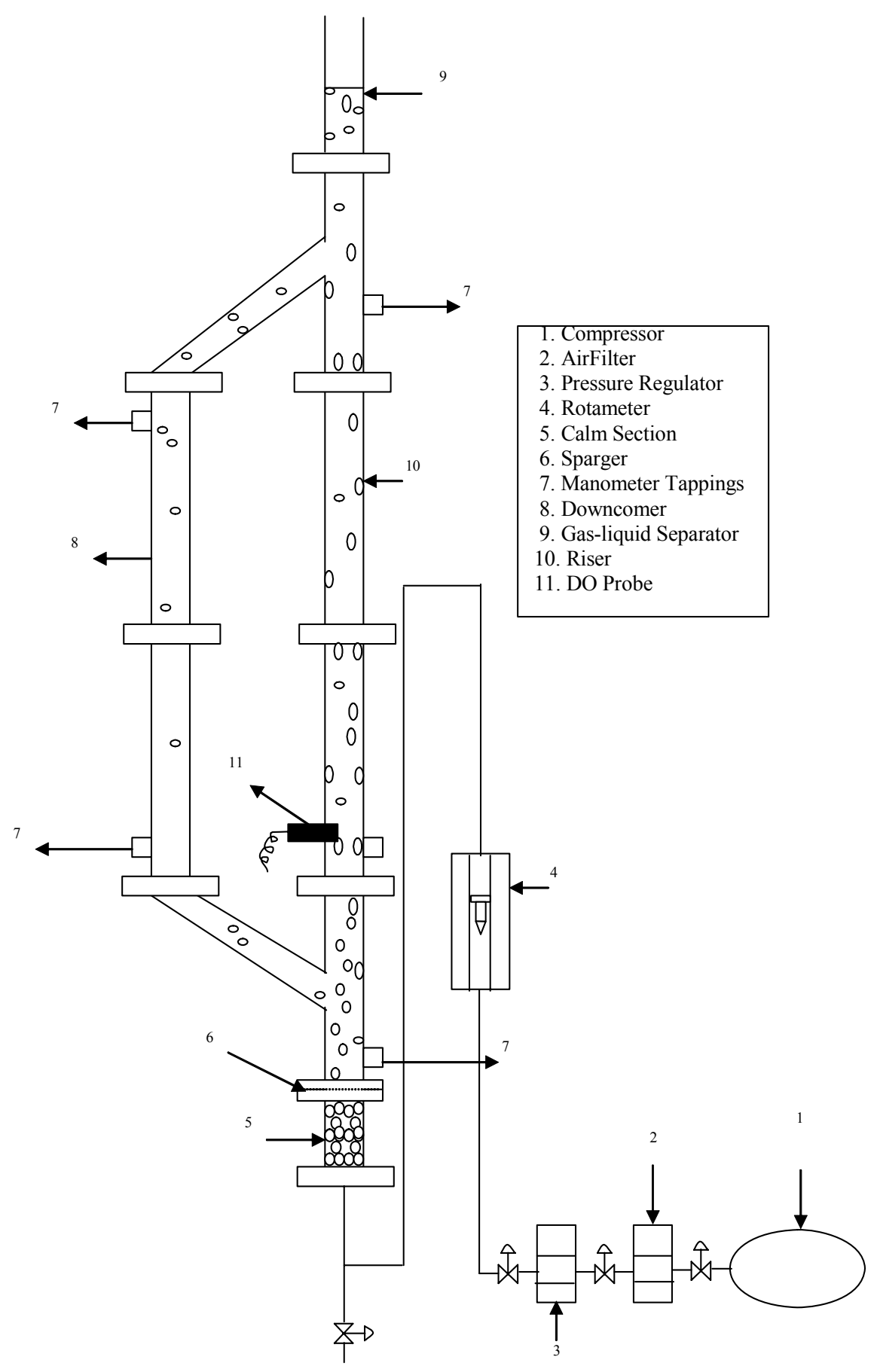

Figure 1. Schematic diagram of external loop airlift column 


$$
\phi_{s}=-\frac{\rho_{l}}{\left(\rho_{s}-\rho_{l}\right)} \frac{\Delta h}{z}
$$

\subsection{Measurement of liquid circulation velocity}

The liquid circulation velocity in the downcomer of the column was determined by tracer technique using $10 \mathrm{~mm}$ polystyrene spherical particle of density of $1012 \mathrm{~kg} / \mathrm{m}^{3}$. The time required for the particle to travel between two ports on the wall of the downcomer was observed to calculate the liquid circulation velocity in the downcomer $\left(U_{l d}\right)$. Thirty measurements were taken for each calculation of liquid velocity in the downcomer. The measurement of tracer particle traveling close to the column wall was excluded from the data (Bello et al., 1984; Kawase, 1990; Kemblowski et al., 1993; Wang et al., 2003).

The liquid circulation velocity in the riser and downcomer were obtained by

$$
\begin{aligned}
& U_{l d}=x_{c} / t_{c} \\
& U_{l r} A_{r}=U_{l d} A_{d} \\
& U_{l r}=U_{l d}\left(A_{r} / A_{d}\right)
\end{aligned}
$$

\section{Results and discussion}

3.1 Variation of gas holdup in the riser with superficial gas velocity for air-alcohol-solid systems

The variation of gas holdup in the riser, $\varepsilon_{\mathrm{gr}}$ with superficial gas velocity for air-alcohol-solid systems is shown in Figure 2. The experiments were carried out with an optimized solids loading of $2000 \mathrm{ml}$. It was observed that the $\varepsilon_{\mathrm{gr}}$ increased linearly with increase in superficial gas velocity. The presence of alcohol surfactants increased the $\varepsilon_{\mathrm{gr}}$. This was mainly due to the suppression of bubble coalescence i.e. number of small bubbles produced in the riser had an insufficient bubble rise velocity to escape from the liquid. A similar trend was observed by Koide et al. (1985), Nicol and Davidson (1988) and Al-Masry and Dukkan (1997).

\subsection{Effect of alcohol concentrations on $\varepsilon_{g r}$}

The effects of propanol and isoamyl alcohol concentrations on $\varepsilon_{\mathrm{gr}}$ are shown in Figures 3 . The addition of propanol and isoamyl alcohol was found to increase the $\varepsilon_{\mathrm{gr}}$. The bubble diameter and bubble rise-velocity were the functional parameters, which govern the riser gas holdup for alcohol surfactants. The increase in concentration of surfactants decreased the bubble diameter and rise velocity, which increased the $\varepsilon_{\mathrm{gr}}$. This may be due to the decrease in the surface tension of the liquid phase.

\subsection{Variation of liquid circulation velocity in the riser with superficial gas velocity for air-alcohol-solid systems}

The variation of liquid circulation velocity, $\mathrm{U}_{\mathrm{lr}}$ with superficial gas velocity for three-phase systems is shown in Figure 4. It was found that an increase in the superficial gas velocity increased the $\mathrm{U}_{\mathrm{lr}}$. The addition of alcohol surfactants decreased the $\mathrm{U}_{\mathrm{lr}}$. It was also observed that the concentrations of alcohol surfactants did not have any marginal effects on the $\mathrm{U}_{\mathrm{lr}}$, which was obtained by Al-Masry and Dukkan.

\subsection{Effect of alcohol concentrations on $U_{l r}$}

The effect of propanol and isoamyl alcohol concentrations on $U_{\text {lr }}$ is shown in Figures 5 for $2000 \mathrm{ml}$ solids loading. It was observed that the addition of solids and an increase in alcohol concentration decreased the $\mathrm{U}_{\mathrm{lr}}$. The alcohol surfactants did not have any marginal effects on the $\mathrm{U}_{\mathrm{lr}}$. A same trend was reported by Al-Masry and Dukkan. 
Vol. 1, No. 1, 2009, pp. 245-253

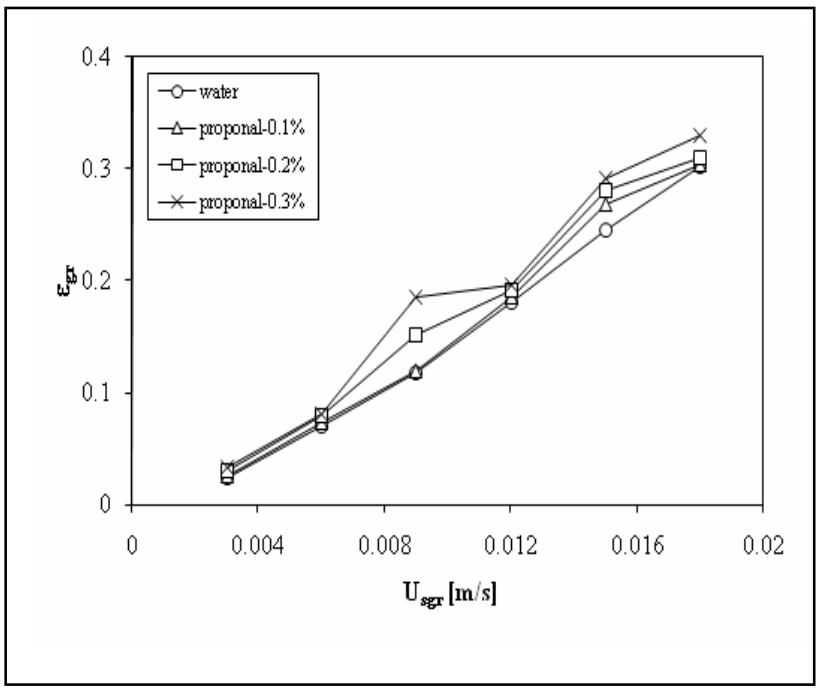

a

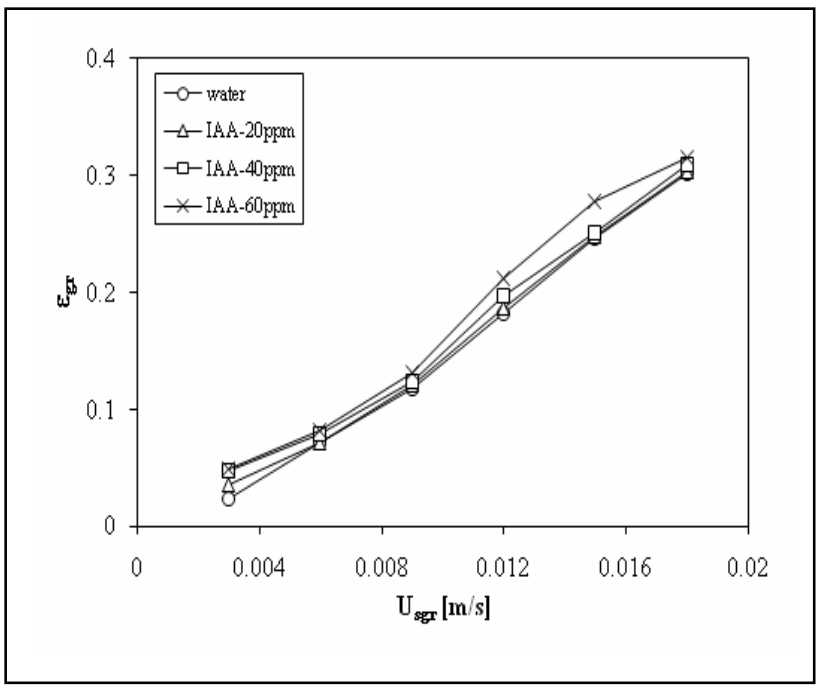

C

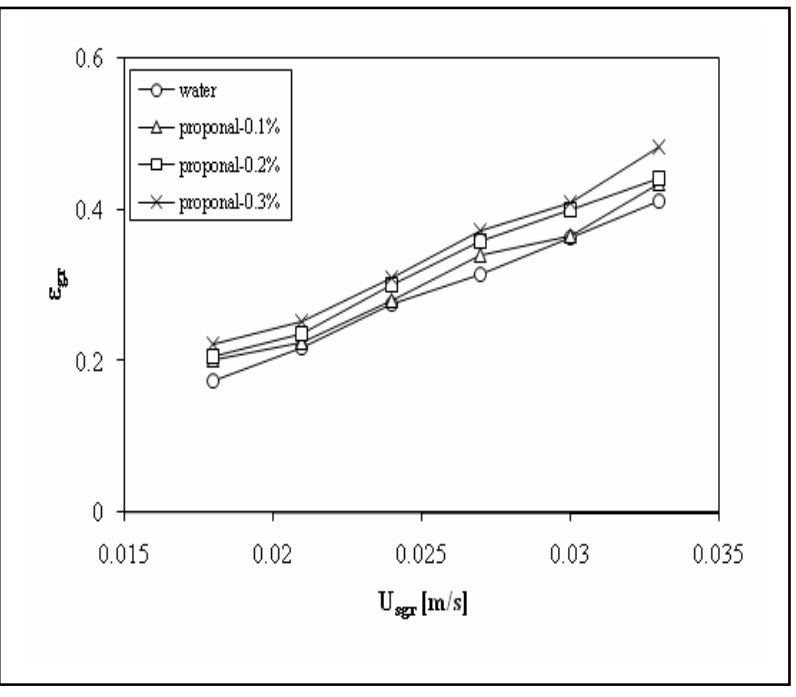

b

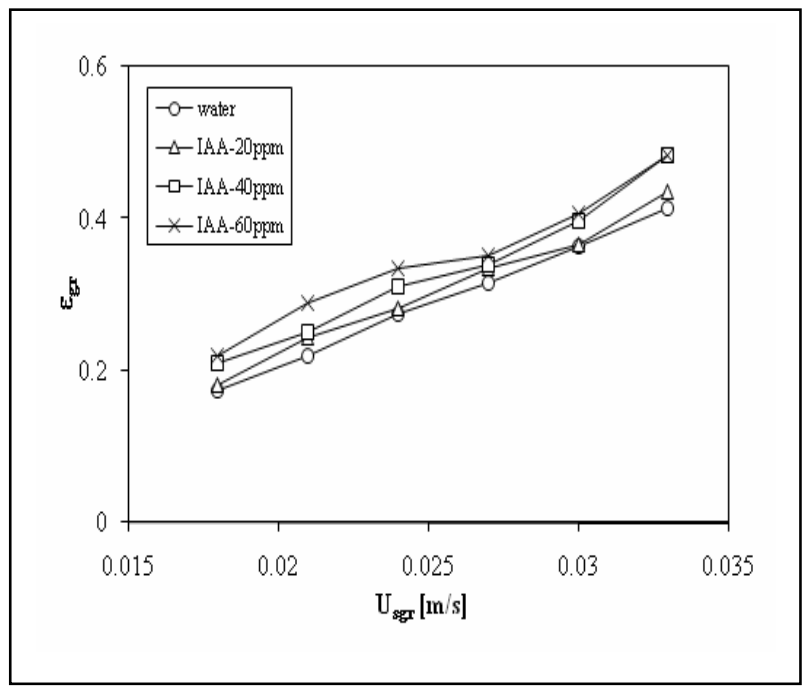

d

Figure 2. Variation of gas holdup in the riser with superficial gas velocity for (a) Air-propanol-polystyrene system; (b) Airpropanol-nylon-6-system; (c) Air-IAA-polystyrene system; (d) Air-IAA-nylon-6 system 


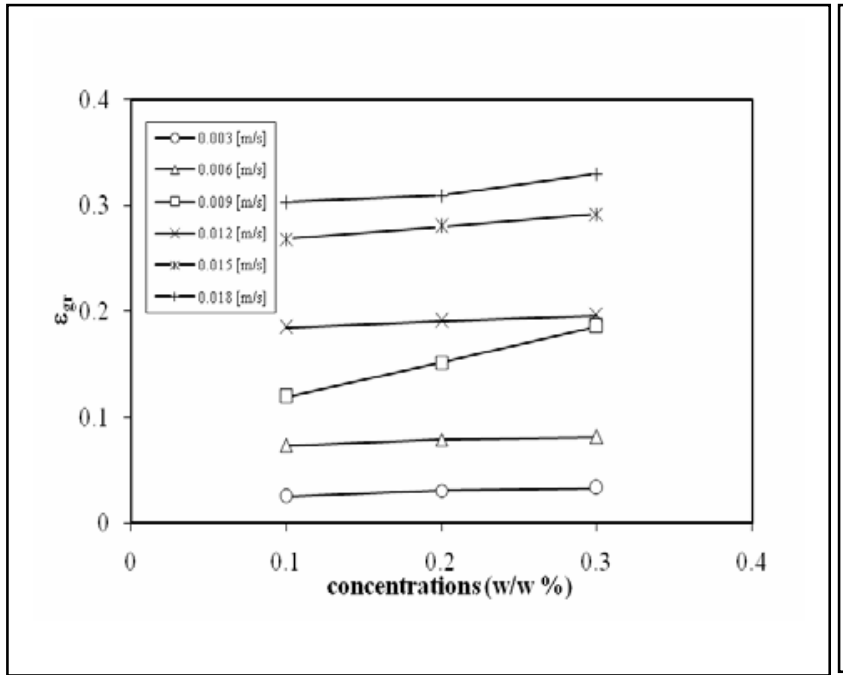

a

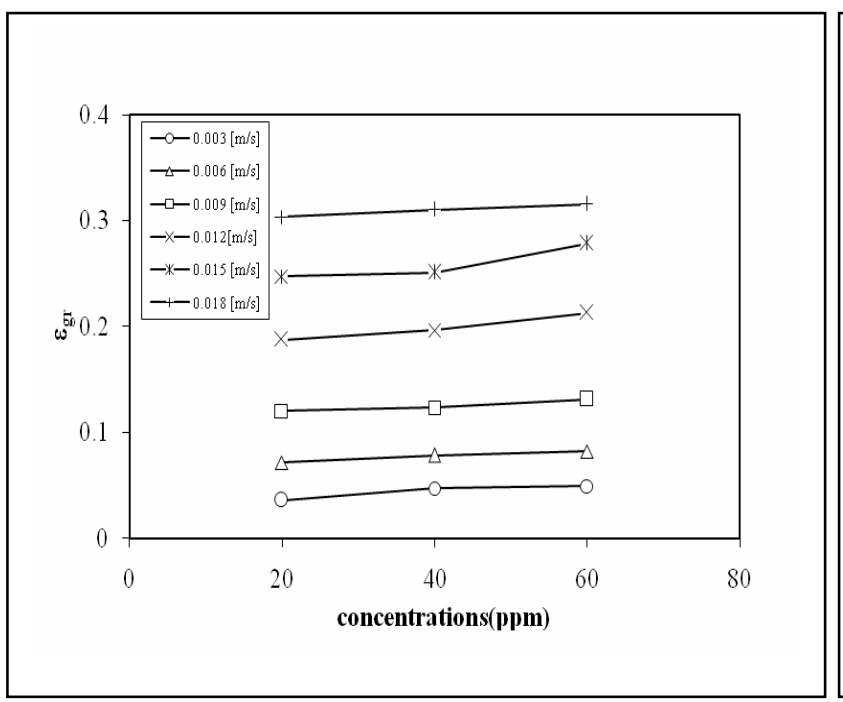

$\mathrm{C}$

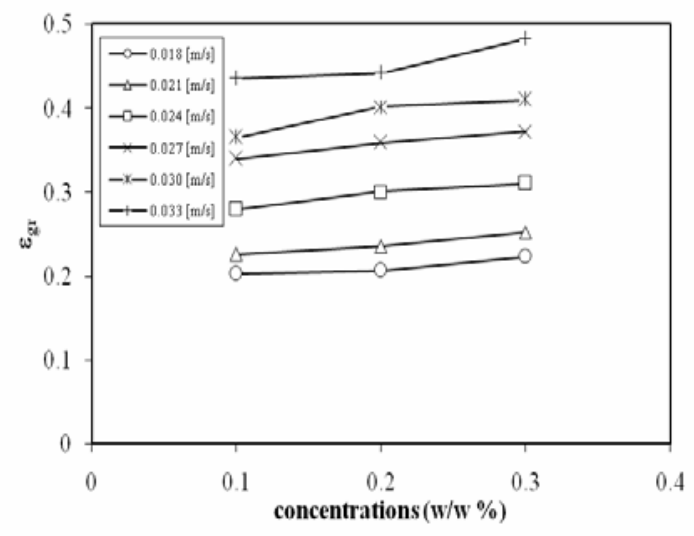

b

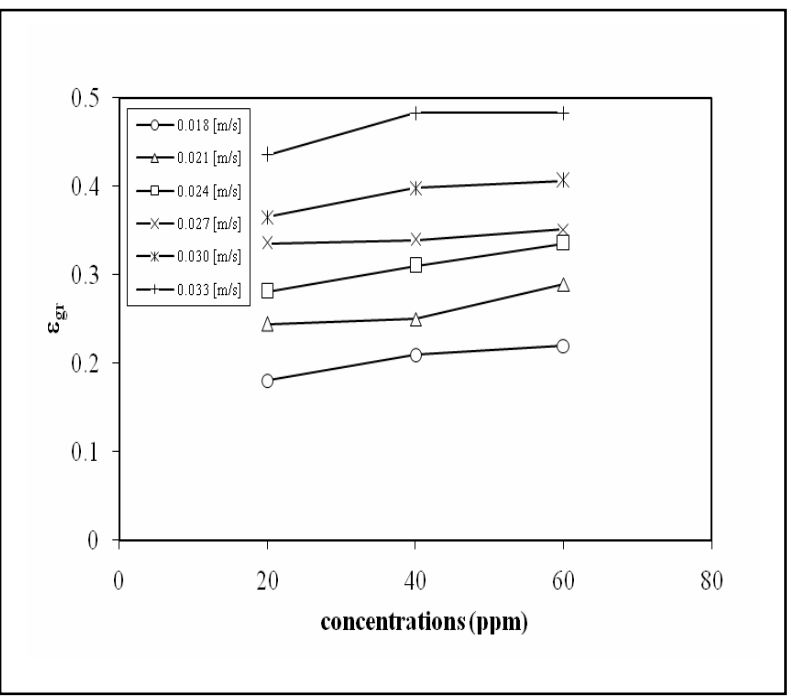

d

Figure 3. Effect of alcohol concentrations on $\varepsilon_{\text {gr }}$ for (a) Air-propanol-polystyrene system; (b) Air-propanol-nylon-6-system; (c) Air-IAA-polystyrene system; (d) Air-IAA-nylon-6 system 
Vol. 1, No. 1, 2009, pp. 245-253

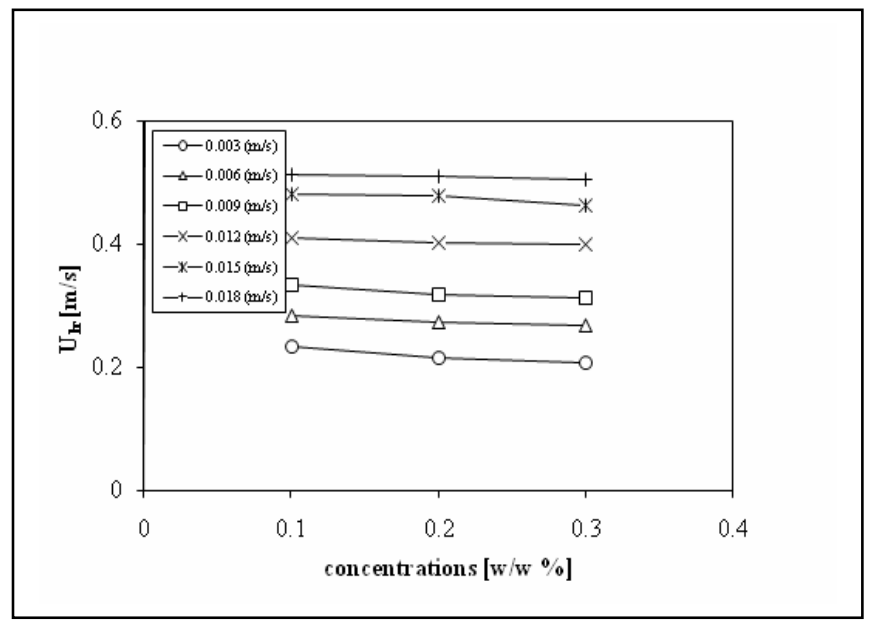

Figure 4. Variation of liquid circulation velocity in the riser with superficial gas velocity for air-propanol-polystyrene system

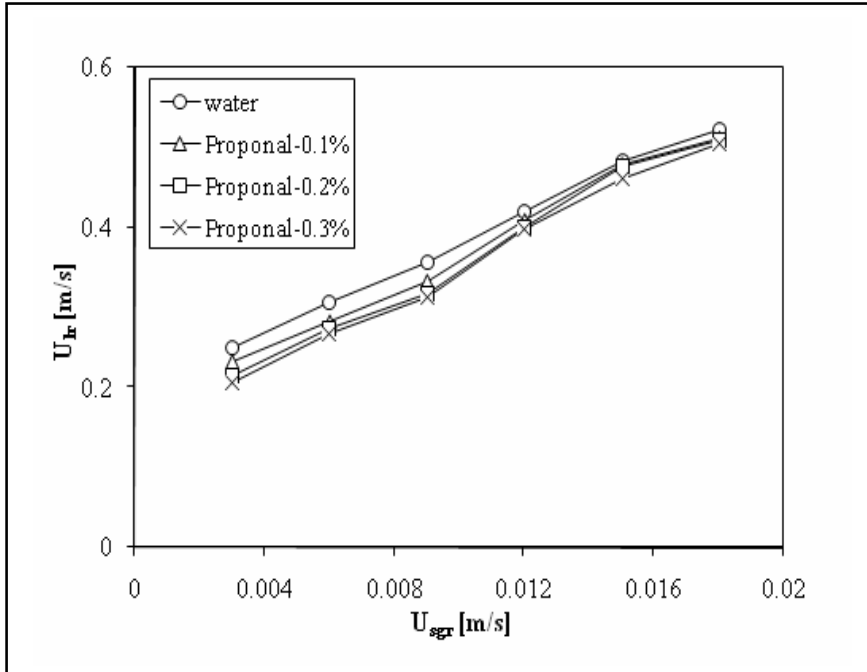

a

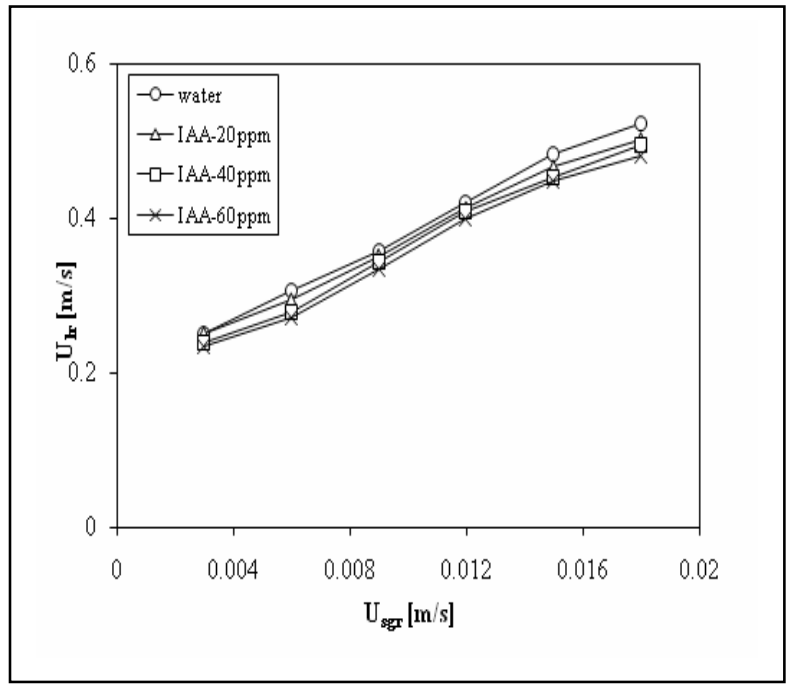

b

Figure 5. Effect of alcohol concentration on liquid circulation velocity in the riser for (a) air-propanol-polystyrene system; (b) air-IAA-polystyrene system

\subsection{Correlation for gas holdup in the riser and liquid circulation velocity for air-alcohol-solids system}

The value of gas holdup in the riser and liquid circulation velocity in the riser for three-phase system have been correlated as

$$
\begin{array}{ll}
\in_{g r}=18.577 U_{s g r}{ }^{\left(0.984+1.16 \times 10^{-4} C_{s}\right)} \sigma^{0.05} \rho_{l}^{-0.038} \mu_{l}^{0.996} & \mathrm{R}^{2}=0.93 \\
U_{l d}=U_{l r}=2.727 U_{s g r}{ }^{\left(0.384+6.52 \times 10^{-5} C_{s}\right)} \sigma^{-0.0096} \rho_{l}^{-0.0034} \mu_{l}^{0.997} & \mathrm{R}^{2}=1 \\
0 \leq U_{s g r} \leq 0.033 &
\end{array}
$$

Parity plots between experimental and predicted values of $\varepsilon_{\mathrm{gr}}$ and $\mathrm{U}_{\mathrm{lr}}$ based on the proposed empirical equations 6 and 7 for airalcohol-solids system are shown in Figures $6 \mathrm{a}$ and $\mathrm{b}$ respectively. The average RMS error for $\varepsilon_{\mathrm{gr}}$ and $\mathrm{U}_{\mathrm{lr}}$ are 11.6 and $3.8 \%$ respectively. It was found that the proposed equations fitted the experimental data well within \pm 30 and $\pm 14 \%$ respectively. 


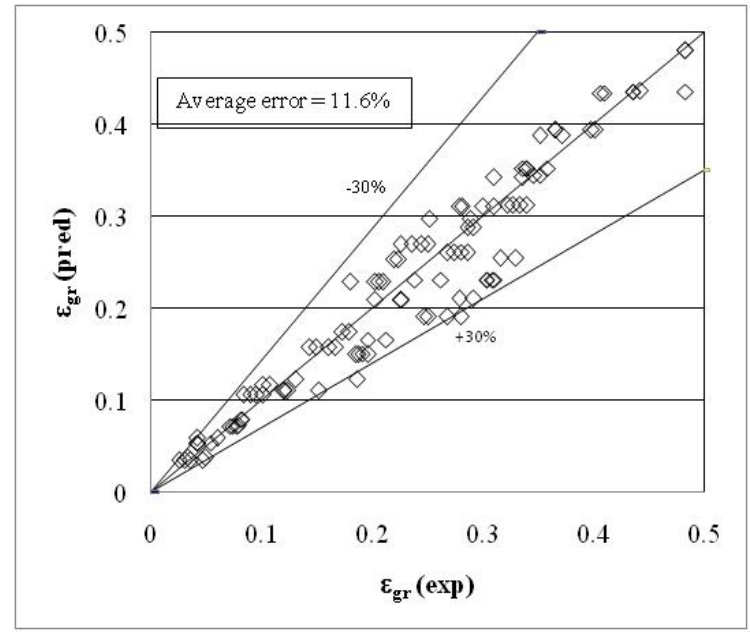

a

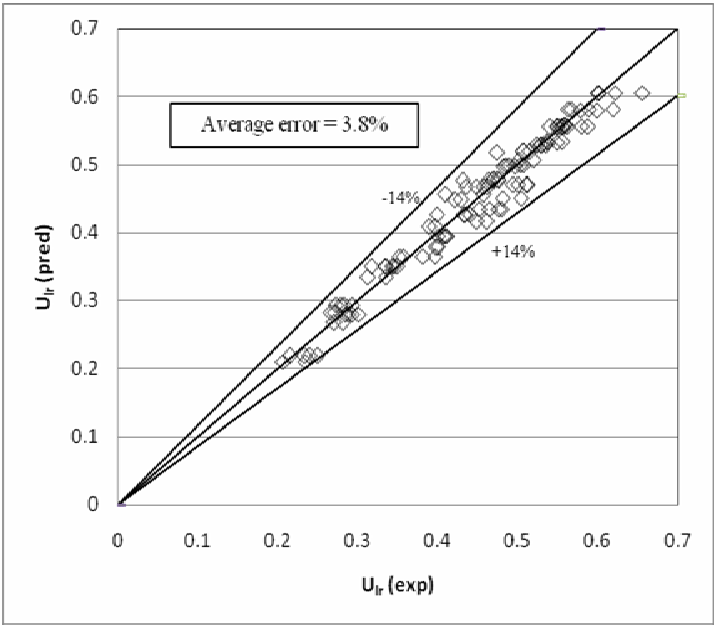

$\mathrm{b}$

Figure 6. Parity diagram of predicted and experimental values for (a) $\varepsilon_{g r}$ estimated from empirical Eqn 6 for air-alcohol-solid system; (b) $U_{l r}$ estimated from empirical Eqn 7 for air-alcohol-solid system.

\section{Conclusions}

The gas holdup in riser, $\varepsilon_{g r}$ increased linearly with increase in superficial gas velocity. The addition of propanol and isoamyl alcohol was found to increase the $\varepsilon_{g r}$. An increase in the superficial gas velocity increased the liquid circulation velocity in the riser, $U_{l r}$. It was observed that the addition of solids and an increase in alcohol concentration decreased the $U_{l r}$. The proposed correlations for gas holdup in the riser and liquid circulation velocity predicted the experimental data well for air-alcohol (propanol and isoamyl alcohol)-solid system.

\section{Nomenclature}

$A_{d} \quad$ downcomer cross sectional area, $\mathrm{m}^{2}$

$A_{r} \quad$ riser cross sectional area, $\mathrm{m}^{2}$

$C_{s} \quad$ solids loading, w/v

$d \quad$ diameter, $\mathrm{m}$

$t_{c} \quad$ time taken between two peaks, $\mathrm{s}$

$U_{s g r} \quad$ superficial gas velocity in the riser, $\mathrm{m} / \mathrm{s}$

$U_{l r}, U_{l d}$ liquid circulation velocity in the riser and the downcomer, $\mathrm{m} / \mathrm{s}$

$x_{c} \quad$ distance between the two adjacent peaks, $\mathrm{m}$

IAA iso amyl alcohol

$z \quad$ distance between two ports, $\mathrm{m}$

$\Delta h \quad$ manometric reading, $\mathrm{m}$

Greek symbols

$\varepsilon_{g} \quad$ gas holdup

$\phi \quad$ volume fraction of solids in liquid - solid two-phase slurry

$\sigma \quad$ surface tension, $\mathrm{mN} / \mathrm{m}$

$\mu \quad$ viscosity, $\mathrm{mPas}$

$\rho$ density, $\mathrm{kg} / \mathrm{m}^{3}$

Subscripts

d downcomer

$g \quad$ gas

$l \quad$ liquid

$r$ riser

$s \quad$ solid 


\section{References}

Al-Masry W.A., and Dukkan A.R. 1997. Chem. Eng. J., Vol. 65, pp. 263-271.

Bello R.A., Robinson C.W. and Moo-Young M. 1984, Can. J. Chem. Eng., Vol. 62, pp. 573-577.

Blazej M., Cartland Glover G.M., Generalis S.C. and Markeos J. 2004. Chem. Eng. Proc., Vol. 43, pp. 137-144.

Choi K.H. 2001. Korean J. Chem. Eng., Vol. 18, No. 2, pp. 240-246.

Del Pozo M., Briens C.L. and Wild G. 1994. Chem. Eng. J., Vol. 55, pp. 1-14.

Douek R.S., Livingston A.G., Johansson A.C., and Hewitt G.F. 1994. Chem. Eng. Sci., Vol. 49, No. 22, pp. 3719-3737.

Freitas C., and Teixeira J.A. .1998. Biotechnol. Techn., Vol. 12, No. 3, pp. 219-224.

Freitas C., Fialova M., Zahradnik J., and Teixeira J.A. .2000. Chem. Eng. Sci., Vol. 55, pp. 4961-4972.

Guo Y.X., Rathor M.N., and Ti H.C. .1997. Chem. Eng. J., Vol. 67, pp. 205-214.

Herskowitz M., and Merchuk, C.J. .1986. Can. J. Chem. Eng., Vol. 64, pp. 57-61.

Kawase Y. 1990. Biotechnol. Bioeng., Vol. 35, pp. 540-546.

Kemblowski Z., Przywarski J. and Diab A. 1993. Chem. Eng. Sci., Vol. 48, No. 23, pp. 4023-4035.

Kochbeck B., Lindert M., and Hempel D.C. 1992. Chem. Eng. Sci., Vol. 47, No. 13/14, pp. 3443-3450.

Koide K., Horibe K., Kawabata H., and Ito S. 1985. J. Chem. Eng. Japan, Vol. 18, No. 3, pp. 248-254.

Meng A.X., Hill G.A. and Dalai A.K. 2002. Can. J. Chem. Eng., Vol. 80, pp. 194-199.

Merchuk J. C. and Siegel, H. 1988. Chem. Teeh. Biotechnol., Vol. 41, p. 105.

Nacef S., Wild G., Laurent A. and Kim S.D. 1988. Entropie, Vol. 143-144, pp. 83-101.

Nicol R.S., and Davidson J.F. 1988. Chem. Eng. Res. Dev., Vol. 66, pp. 159-164.

Posarac D., and Petrovic D. 1988. Chem. Eng. Sci., Vol. 43, No. 5, pp. 1161-1165.

Prakash A. 1991. Enhancement of gas-liquid and particle-liquid mass transfer in bubble columns and three-phase fluidized beds.

Ph.D. Thesis. The University of Western Ontario, London, Canada.

Saberian-Broujenni M., Wild G., Charpentier, J.C., Fortin, Y., Enzen, J.P. and Patoux, R., 1984. Entropie, Vol. 120, pp. 30-44.

Shimizu K., Takada S., Takahadhi T. and Kawase Y. 2001. Chem. Eng. J., Vol. 84, pp. 599-603.

Song, G.H., Bavarian, F. and Fan, L.S. 1989. Can. J. Chem. Eng., Vol. 67, pp. 256-275.

Vial C., Poncin S., Wild G. and Midoux N. 2001. Chem. Eng. Proc., Vol. 40, pp. 130-151.

Wang S., Arimatsu Y., Koumatsu K., Furumoto K., Yashimoto M., Fukunaga K. and Nakao K. 2003. Chem. Eng. Sci., Vol. 58, pp. 3353-3360.

Wenge F.W., Chisti. M.Y., and Moo-Young M. 1995. Ind. Eng. Chem. Res., Vol. 34, pp. 928-935.

\section{Biographical notes}

Dr. V.Sivasubramanian is Associate Professor in Chemical Engineering at National Institute of Technology Calicut, India. His research has focused on "Wastewater Treatment using Inverse Fluidized Bed Reactor" and "Treatment of Effluent using Biomembrane Techniques". He is the author of over 20 articles which have appeared in journals such as Asia-Pacific J Chem Eng., J Chem Technol Biotechnol., J Chem Eng Japan, IETECH J Mech Design, J Indian Chem Engr and Rubber India. He is also author of a book titled, "Process Economics and Industrial Management". He is the recipient of the award and first prize for an oral presentation from Prof. M. M. Sharma in CHEMCON 2004, Mumbai, India. He is Editor in Intern J Eng., Sci Technol, Nigeria and Medwell Journals. He is also reviewer in Clean, Elsevier, USA, Asia-Pacific J Chem Eng, Wiley Interscience, Australia, Chem Product and Process Modeling, The Berkeley Electronic Press, USA, Chem Eng Sci, Adv Powder Technol, Elsevier, Desalination Journal, Elsevier, USA, Intern J Biotechnol., Inderscience Publishers, Intern J Chem Reactor Eng, The Berkeley Electronic Press, USA, Intern J Eng, Science and Technology, Nigeria and Indian J Sci and Technol.

Mr. B.S. Naveen Prasad is Faculty in Chemical Engineering Department at Sathyabama University, Chennai, India. He did his graduation in Chemical Engineering at Kongu Engineering College, Erode. Bharathiar University, Coimbatore. He completed his M.S. (By Research) programme in the Department of Chemical Engineering, A. C. College of Technology, Anna University, Chennai. He registered for his Doctoral programme in Biotechnology Department at Sathyabama University, Chennai. 